skirts of Stockholm. One of the largest and most important departments is that for the production of horse serum. The stables with boxes for about eighty horses have been built with slanting lanternine roofs which let in the light above the boxes, and every box is provided with running water. Each of the horses produces about seven litres of blood, or raw serum, a week. Hot and cold air is supplied according to the season. In another and equally well-kept section are quarters for a large number of calves. The Institute comprises three sections : a pathological, a bacteriological and a serological section, which are supplemented by a mechanical and a parasitic laboratory. Altogether about 150 persons are employed. The new Institute provides increased facilities for effective combating of diseases of domestic animals, which still cause heavy losses.

\section{American Birth-rate}

Accordrng to statistics of the Metropolitan Life Insurance Company (J. Roy. Inst. Pub. Health and Hyg., Jan. 1945), young mothers between the ages of twenty and thirty having their first child have been the principal contributors to the rapid war-time rise in the American birth-rate. The chief factor in the rise at these younger ages has been the increase in the marriage-rate, but a good part of the rise has been accounted for by women who had delayed having children until economic conditions were more favourable. Although the general birth-rate increased rapidly during the war period, the trend towards small American families as well is still in evidence, and families with five or more children continue to decrease.

\section{Bright Light Sources}

A PAPER read by J. N. Aldington on November 14 last before the Illuminating Engineering Society gave a general survey of tungsten filament projector lamps, showing the trend of recent developments in this field. The paper embraces consideration of the characteristics of tungsten filaments in vacuo and in gaslamps employing both single-wound and doublewound helices, multi-filament lamps, and symmetrical light sources. Various types of lamps are illustrated photographically, and lamp performance data are given in tabular form.

\section{Dried Starfish as Chicken Meal}

Iт is reported (J.Amer. Vet. Med. Assoc., 55, 151 ; 1944) that starfish, collected in the process of cleaning oyster beds, are now being dried and ground up to make chicken meal. An analysis of the meal showed that it contained 30.7 per cent protein, $17 \cdot 6$ per cent calcium and 0.35 per cent phosphorus. Tested against sardine fish meal of equal protein value, it proved its value as food; but its use had to be limited to $3 \cdot 5-5$ per cent of the total ration, because of the high proportion of calcium.

\section{University of London}

The title of 'professor emeritus' in the University of London has been conferred on the following: Prof. R. H. A. Plimmer, who held the chair of chemistry at St. Thomas's Hospital Medical School during 1922-42; Sir Owen Richardson, who held the Wheatstone chair of physics at King's College during 1914-24 and the Yarrow Research professorship of the Royal Society attached to King's College during 1924 44 ; Dame Helen Gwynne-Vaughan, who held the ehair of botany at Birkbeck College from 1921 until her retirement in 1944 and was a member of the Senate as a representative of the Faculty of Science during 1929-34; Prof. Eva G. R. Taylor, who held the chair of geography at Birkbeck Colloge from 1930 until her retirement in 1944.

Dr. C. W. Shoppee has been appointed to the University readership in chemistry tenable at the Royal Cancer Hospital (Free). Since 1939 he has been working at the Pharmaceutical Institute in the University of Basle.

The title of professor of mathematics in the University has been conferred on Dr. Paul Dienes, in respect of the post held by him at Birkbeck College.

\section{Announcements}

The Medical Research Council has appointed Prof. A. A. Miles, professor of bacteriology at University College Hospital Medical School, London, to the staff at the National Institute for Medical Research as from October 1, 1945, with the view of his becoming director of the Department of Biological Standards on the retirement of Sir Percival Hartley next year.

Prof. F. Y. Henderson, reader in timber technology in the University of London and assistant professor in timber technology in the Imperial College of Science and Technology, has been appointed director of Forest Products Research in the Department of Scientific and Industrial Research on the forthcoming retirement of Mr. W. A. Robertson, who has been director since 1933 .

Mr. V. M. Wadsworth has been appointed assistant lecturer in agricultural economies in the University of Leeds.

M. Turgut Erem, the first educational attaché to be appointed to the Turkish Embassy in Great Britain, has arrived in London; he will act as inspector of Turkish students in Britain, of whom there are now about a hundred, including eighteen holders of scholarships awarded by the British Council, with which M. Erem will be in close touch.

The Institution of Civil Engineers, with the Institution of Municipal and County Engineers, have appointed a joint committee to draw up notes for the use of engineers on the best location of underground services. The Committee will consist of $\mathrm{Mr}$. W. H. Morgan, county engineer of Middlesex, as chairman, and ten other members; representatives of electricity and gas supplies and post office services have been nominated by or in consultation with the Institution of Electrical Engineers, the Institution of Gas Engineers and the chief engineer, G.P.O. respectively. Communications should be addressed to the Secretary, Joint Committee, c/o Secretary, Institution of Civil Engineers, Great George Street, Westminster, London, S.W.1.

THE following appointments have been made in the Colonial Service: C. F. Charter, to be soil chemist, Gold Coast; R. W. Crowther and D. A. W. Walker, to be veterinary officers, Nigeria; Miss M. E. Broughton, to be marketing officer, Nigeria; F. E. Luscombe, to be agricultural officer, Tanganyika; C. Harvey, senior agricultural officer, Fiji, to be director of agriculture, Fiji; E. W. Leach, senior agricultural officer, Nigeria, to be deputy director of agriculture, Trinidad; F. S. Collier, conservator of forests, Nigeria, to be deputy chief conservator of forests, Nigeria. 